\title{
De krant: Een cultuurgeschiedenis
}

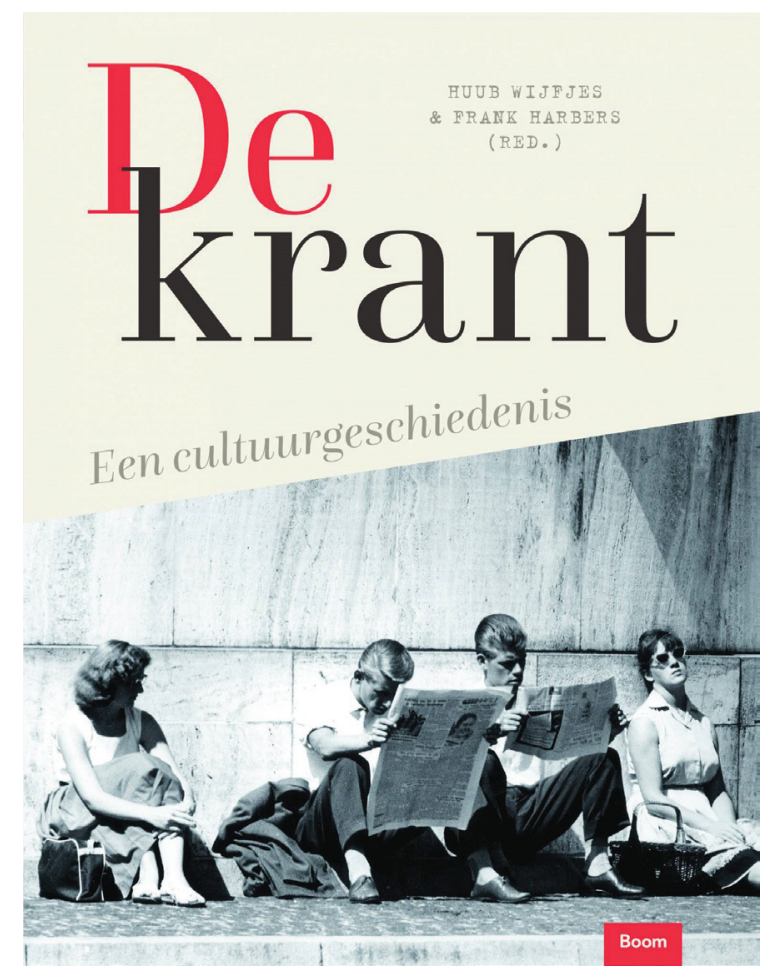

\section{Huub Wijfjes and Frank Harbers (eds.)}

De krant: Een cultuurgeschiedenis

(Amsterdam: Boom, 2019), 352 pp.

isbn 9789024419814

\begin{abstract}
Reviewed $b y$
Jesper Verhoef (Utrecht University) is a cultural historian whose research has focused on Dutch history, media history, identity formation and digital humanities.
\end{abstract}

For well over a decade the Dutch National Library (KB) has been at the forefront of digitising historical sources. Its interface Delpher.nl allows for keyword searches in a plethora of publications. Delpher's showpiece is the ever-growing collection of about fifteen million Dutch newspaper pages spanning the years 1618-2005. Many scholars have cautioned that digitised newspaper articles need to be properly contextualised and historicised in order to do the medium they appeared in justice and not lose meaning. In 2019 one of them, the grand old man of Dutch media history Huub Wijfjes, produced the best antidote possible to such historical-contextual ignorance. Together with press historian Frank Harbers he edited De krant: Een cultuurgeschiedenis [The Newspaper: A Cultural History], the first volume in a series - edited by Wijfjes, too - that is to record 
the cultural history of various media in the Netherlands. It consists of an introduction followed by eight chapters, each written by one or two (media) historians, that chronologically cover four centuries of Dutch newspaper history.

In their introduction, Wijfjes en Harbers historicise newspaper research. The focus lies on Dutch history, as is the case in all chapters, though they occasionally zoom out and put developments in international perspective. As a consequence of the Cultural Turn of the 1980s Dutch press historians adopted a new 'integral' approach. They started to conduct large-scale historical research that not only paid attention to institutional aspects of newspapers, but also to journalistic practices and output, e.g. style, form and content. It came to be acknowledged that newspapers are not isolated phenomena, but are entangled with societal, political and cultural processes. Newspaper history, then, has since become cultural history.

This volume builds on this integral approach. The editors proclaim it is a textbook in which topics are 'synthetically elaborated by specialists.' This claim is at once modest and challenging. Modest in the sense that the lion's share of this volume is comprised of secondary research - incidentally to a considerable degree underpinned by primary research carried out by the contributors, most of which are leading experts with decades of experience. Moreover, the introduction states that the book is not a 'classical reference work, with all the important facts lined up.' This is a wise choice which has resulted in relatively concise chapters, especially given the fact that all but two chapters cover a period of fifty years or longer. Chapters are dense, yet, impressively, still make for a pleasant read. The challenge of syntheses is to form an addition to existing research. This volume meets this challenge. Chapters build on each other and are coherent. Each one clearly positions newspapers in their political, social and cultural context, tracks developments in regard to readership and journalistic culture and devotes attention to content and form. Time and again, authors highlight continuities and discontinuities over long stretches of time. Consequently, the volume is more than the sum of its parts and lives up to its title. The first chapter, by Esther Baakman and Michiel van Groesen, narrates how Dutch newspapers - the oldest surviving edition appeared in 1618 - would become iconic in the relatively open discussion culture of the Dutch Republic. Amsterdam turned into the news centre of Europe and newspapers became an export product. The authors highlight that there was no linear development toward press freedom, though: this freedom was frequently curbed, particularly in times of politic upheaval. The same goes for the eighteenth century, in which the Dutch newspaper market expanded incrementally, the second chapter shows, written by Joop Koopmans. Analogous to the first chapter, it nuances the role the newspaper had in disseminating news. Other publications such as pamphlets were important, too, and boundaries between them were fluid. Of note is that economic motives still had clear precedence over political ideals. When the political pendulum swung, 
newspapers adapted their outlook accordingly.

This was not considered problematic because newspapers were primarily a news outlet.

This changed from the 1780s onwards. Significant prior knowledge of Dutch political history is required to comprehend the intricate politic conflicts - including civil war, revolution and occupation by Napoleonic France - that ensued over the next 35 years. Koopmans's main point is clear, however: newspapers became more political. They started 'to stimulate opinion formation in the public sphere.'

This new function was short-lived, Remieg Aerts shows in chapter three. The constitution of 1815 formally granted press freedom. However, the Restoration Regime muzzled the press and hindered the emergence of a public sphere or vibrant civil society, among others by employing spies and informants. Interestingly, the governments of France, Prussia, Austria and Russia encouraged king William I to take such measures. They wanted to halt the dissemination of subversive messages of revolutionaries that had found refuge in Brussels. To add insult to injury, a practical legacy of the French occupation was the tax levied on paper. Consequently, newspapers became more expensive, more elitist and, importantly, unable and unwilling to opine. Tellingly, English man of letters John Bowring, who travelled through the Netherlands, concluded that he knew no other civilised country that showed so little interest in public affairs. In the 1840s, after the secession of Belgium, newspapers took on a more political role yet again. They became centres of political groupings, 'a kind of proto party formations.' In other words, the contours of pillarization - a staple characteristic of the Netherlands in the finale stage of the nineteenth and first half of the twentieth century - appeared at the horizon.

After the tax on paper was revoked in 1869 , newspapers truly became a mass medium, Frank Harbers notes in chapter four. They began 'to play an ever more important role in public life and in the formation of the public opinion and a collective identity.' A considerable portion of newspapers committed themselves to a political or religious cause and thus formed a catalyst for pillarization. Because this history is well-known, it is commendable that Harbers mainly focuses on the rise of New Journalism, which was inspired by foreign examples. Pillarization, the Dutch 'subscription culture' (the reader would have liked to learn how this typical Dutch feature affected newspapers in more recent eras, too) and fear of Americanisation and 'sensationalism' all put a damper on this new journalistic approach. Still, it led to a fierce debate about journalistic culture and norms, which was fuelled by and continued after the First World War.

Chapter five, by Thomas Smits, is devoted to the 'explosion of images,' a relatively understudied aspect of newspaper history. Smits pinpoints the rise of illustrations and the transition to photographs. Additionally, he chronicles the opposition which images aroused.

Harbers's and Smits's chapters raise an important question: to what extent was criticism directed at 
newspapers entangled with wider cultural pessimism that also surfaced in the public debates about film during the Interwar years? Similar questions about the interrelatedness of responses to media (innovations) can be asked in regard to other eras. Understandably, these fall outside the scope of this volume. It is to be hoped, however, that this book will urge scholars to not only write more cultural histories of single media - as important and welcome as these are - but eventually write a cultural history of the Netherlands using numerous media as a lens. Mariëtte Wolf and Frank van Vree engage with the Second World War in chapter six. Though especially after 'Stalingrad' illegal papers published by the resistance mushroomed, their conclusion is distressing. During the entire War the majority of legal newspapers dutifully complied with the 'new order' and showed no signs of resistance whatsoever. In adapting 'to prevent worse,' they effectively became Nazi mouthpieces.

Among other things, chapter seven, written by Pien van der Hoeven en Wijfjes, highlights how newspapers underwent a metamorphosis in the 1960s. From biddable and conservative bulwarks, newsrooms turned into breeding grounds for progressive and autonomous journalists. At the same time, most pillarized newspapers cut ties with the church and/or political party they had aligned themselves with and coverage became both more extensive and profound. As a result, newspapers proved to be up to the challenge posed by television. Van der Hoeven en Wijfjes stress that journalists did not merely report or reflect wider societal and cultural changes of the 1960s, but rather helped bring these about. This begs the question to what extent the same can be said about the neoliberal paradigm that has held sway over the last forty years. This question is not addressed, perhaps because the cultural history of the Netherlands of these decades is yet to be written.

In the final chapter Marcel Broersma ‘impressionistically’ sketches how newspapers have fared since the emergence of the Internet in the mid-1990s. He makes some interesting remarks. To give one example, he questions the increase of vox pops, for these might increase rather than decrease distrust in news. All in all, he is positive about the prospects of newspapers. He ends with a warning, though. A gap has emerged between those willing to pay for journalism and those who are not reminiscent, one might ponder, of the one between haves and have-nots and anywheres and somewheres. As a consequence, newspapers lose the integrative function' they had in the twentieth century.

On a final note, this book is richly illustrated and beautifully designed. The many photographs depicting readers engrossed in a newspaper in particular bring this history to life and underscore the cultural-historical importance of this study. Moreover, the footnotes and up-to-date reference list enable the enthused reader to quickly navigate primary sources. In this sense, too, this book forms an indispensable point of departure for scholars interested in or using newspapers.

Jesper Verhoef (Utrecht University) is a cultural historian whose research has focused on Dutch history, media history, identity formation and digital humanities. 


\section{TMG Journal for Media History}

Volume 24 No (1/2)/2021

DOI

https://dx.doi.org/10.18146/tmg.804

\section{PUBLISHER}

Netherlands Institute for Sound and Vision

\section{COPYRIGHT}

Each article is copyrighted (c) by its author(s) and is published under license from the author(s). When a paper is accepted for publication, authors will be requested to agree with the Creative Commons Attribution 4.0 International License. 